\title{
Pengantar Redaksi:
}

\section{"Merangkai Kebhinnekaan Indonesia"}

Dalam penerbitan Jurnal Pemikiran Sosiologi Voume 4 Nomor 2 Agustus - Desember 2017 ini Dewan Redaksi Jurnal Pemikiran Sosiologi dari Departemen Sosiologi, Fisipol UGM menghadirkan pembahasan tema utama mengenai kondisi sosial dan praktik keragaman budaya di Indonesia. Pilihan judul penerbitan 'Merangkai Kebhinnekaan Indonesia' memiliki pertimbangan yang didasari oleh kerangka pemikiran sosiologis yang menempatkan pembahasan dan kajian mengenai 'keragaman budaya' (cultural diversity) sebagai suatu konteks sejarah dan perubahan sosial. Keragaman budaya menyediakan peluang untuk menelisik konstruksi sosial yang berlaku di dalam suatu masyarakat, proses perubahan sosial yang menyangkut bagaimana cara-cara manusia memahami dan memaknai keberadaan dirinya sebagai bagian dari suatu masyarakat termasuk cara-cara berkomunikasi, berinteraksi, dan pelembagaannya di dalam bentuk norma dan institusi atau pranata sosial, ekonomi dan politik.

Frasa 'Bhinneka Tunggal Ika' (berbeda-beda di dalam kesatuan) yang berasal dari bahasa Jawa Kuna, merupakan semboyan yang seringkali didengungkan sebagai bagian dari konstruksi nasionalisme Indonesia yang merujuk pada konteks sejarah sosial bangsa Indonesia sebagai suatu kesatuan sosial yang majemuk dan beragam. Kemajemukan menunjuk pada perbedaan yang dimiliki masing-masing entitas budaya, sedangkan keragaman adalah entitas perbedaan budaya yang bermacam-macam bentuk dan wujudnya. Di dalam bahasa Inggris, kemajemukan diterjemahkan menjadi plurality dan keragaman menjadi diversity, suatu pemahaman yang kemudian berkembang lebih lanjut di dalam pembahasan akademis mengenai pluralisme dan multikulturalisme. Ada berbagai pilihan kata untuk menjelaskan bagaimana 'keragaman' dan 'kemajemukan' yang melatarbelakangi kondisi sosial masyarakat Indonesia sebagai suatu negara bangsa pascakolonial itu terbentuk dan berproses. Kita pernah mendengar misalnya slogan 'Merajut Kebhinnekaan', 'Tenun Kebangsaan', 'Merawat Kemajemukan Bangsa' - dan lain sebagainya - kesemuanya itu menjelaskan bagaimana tema mengenai 'kemajemukan dan keragaman' di Indonesia merupakan suatu konstruksi sosial yang tidak terpisahkan dari upaya merekayasa kondisi sosial bangsa Indonesia dalam upaya untuk terus melegitimasikan dan memelihara kohesivitas nasional.

Pilihan judul 'Merangkai Kebhinnekaan' dalam tema penerbitan Jurnal Pemikiran Sosiologi kali ini bukan semata didasari atas pilihan 'slogan' nasionalisme semata, melainkan secara simbolik menunjuk pada suatu lokasi, identitas dan praktik dimana 'kebhinnekaan' di Indonesia selain sebagai suatu sejarah sosial yang tak terelakkan juga merupakan komunitas 
majemuk suatu bangsa yang terus berproses di dalam perubahan sosial. Rangkaian yang dimaksudkan menunjuk pada lokasi geografis dan landskap budaya Indonesia sebagai suatu negara kepulauan (archipelago) yang memiliki norma, tradisi, dan latar belakang budayanya yang beragam, sekaligus juga menunjuk pada bagaimana pola-pola itu disusun (dirangkaikan) dalam konteks pembangunan suatu negara bangsa (nation-state). Saat ini kita menyaksikan bagaimana kondisi kemajemukan dan keragaman budaya di Indonesia mengalami banyak tantangan. Persoalan keadilan sosial dan distribusi kesejahteraan kembali menjadi tugas berat bangsa ini karena sekaligus dihadapkan pada persoalan menguatnya kembali kecenderungan politik identitas. Hal ini nampak menguat misalnya ketika berlangsung kontestasi demokrasi melalui Pemilu dan bahkan pada Pilkada di Indonesia. Berkenaan dengan pentingnya mensosialisasikan kembali wacana tentang kebhinnekaan dan sekaligus keadilan sosial itulah Jurnal Pemikiran Sosiologi menyajikan pilihan tematik mengenai; pluralisme, multikulturalisme dan konstruksi identitas, yang secara sistematis merumuskan pembahasan mengenai; gagasan, wacana dan praktik tentang keragaman budaya di Indonesia; bentuk-bentuk intoleransi dan mobilisasi politik berbasis politik identitas; representasi identitas dan keadilan sosial di Indonesia; ideologi mengenai pluralisme dan kontestasinya; dan munculnya media baru khususnya melalui keberadaan media sosial yang dalam praktiknya ikut menguji kebhinekaan Indonesia.

Ada 9 artikel akademis yang disajikan dalam penerbitan Jurnal Pemikiran Sosiologi Volume 4 No. 2 Tahun 2017 ini. Kesembilan artikel itu merangkum kajian, diskusi, hasil temuan dan rekomendasi dalam upaya 'merangkai kemajemukan dan keragaman' di Indonesia. Artikel pertama disajikan oleh Mustaghfiroh Rahayu yang menelisik tentang sejarah terminologi 'pluralisme dan multikulturalisme' sebagai suatu cara pandang dan mekanisme politik maupun kebijakan dalam merespon keragaman di Indonesia. Artikel ini berangkat dari suatu tinjauan kritis yang membedah konteks penempatan kedua terminologi itu dalam sejarah sosialnya yang spesifik dan bagaimana kondisi sosial di Indonesia dalam perkembangannya merespon pewacanaan mengenai 'pluralisme dan multikulturalisme'. Dalam pembahasan kajian ini, penulis merangkum bahwa Indonesia merupakan suatu negara bangsa yang bersifat multikultural, meskipun bukanlah suatu negara 'multikulturalis'. Hal ini dikarenakan sebagai suatu negara pascakolonial di Asia Tenggara, Indonesia sebagaimana kebanyakan negara-negara Asia lainnya, memiliki sejarah yang berbeda dengan negara-negara multikultural lainnya seperti di Barat. Pemahaman mengenai perbedaan gagasan dan praktik mengelola kemajemukan dan keragaman di Indonesia menjadi penting karena berdampak pada bentuk kebijakan di dalam mengakomodasi keragaman itu sendiri. Artikel kedua disajikan oleh Didimus Dedi Dhosa yang membahas melalui pendekatan studi historis kritis mengenai kesenjangan sosial yang terjadi di Propinsi Nusa Tenggara Timur (NTT) yang justru dilanggengkan oleh sistem kapitalisme warisan 
dari masa kolonial yang membentuk hierarki struktural dan memperoleh legitimasi kultural. Menurut penulis, sistem akumulasi kapital yang terus berlanjut semenjak masa kolonial hingga saat ini menjadi alasan mengapa kesenjangan sosial terus berlanjut bagi sebagian besar bangsa Timor di NTT dikarenakan eksploitasi atas sumberdaya alam hanya menguntungkan segelintir elit saja baik secara nasional maupun di tingkat lokal. Tradisi yang berkembang di dalam masyarakat setempat kemudian digunakan untuk melegitimasi kesenjangan sosial semacam itu sebagai akibat dari dihancurkannya gerakan kiri yang sebelum peristiwa 1965 mengusung gerakan Reformasi Agraria termasuk di wilayah Timor atau NTT sekarang. Artikel ketiga disajikan oleh Anis Izdiha mengenai studi etnografi atas perempuan politik yang berjuang untuk mengakomodasi suara keterwakilan perempuan di parlemen atas pemberlakuan kuota $30 \%$. Kajian ini mengambil studi kasus perempuan politik yang terlibat di dalam partai politik maupun di parlemen daerah (DPRD) di wilayah Propinsi Yogyakarta dan bagaimana mereka masih mengalami banyak hambatan di dalam menjalankan peran-peran politik dikarenakan kuasa patriarkhi yang kuat bukan hanya sebagai suatu sistem nilai yang membatasi ruang gerak kaum perempuan melainkan juga dikarenakan nilai-nilai agama yang justru melegitimasi pembatasan atas ekspresi politik kaum perempuan. Artikel keempat disajikan oleh Nurul Hasfi yang menelisik penggunaan media sosial Twitter dalam kontestasi Pemilihan Presiden (Pilpres) 2014 dimana wacana mengenai politik keshalehan personal dimainkan dengan sengaja sebagai suatu rekayasa memanipulasi daya tarik pemilih (voters) melalui strategi kampanye hitam. Dalam konstruksi mengenai politik keshalehan itu, simbol dan pewacanaan keshalehan dalam merepresentasikan identitas agama Islam para Capres menjadi arena pertarungan kepentingan yang direproduksi melalui media sosial. Pewacanaan mengenai identitas keshalehan agama Islam dalam Pilpres 2014 melalui Twitter karenanya cenderung bersifat degradatif, hal ini karena pewacanaan identitas keagamaaan dianggap gagal berfungsi sebagai suatu proses komunikasi politik yang bersifat netral dalam kontestasi demokrasi. Artikel kelima disajikan oleh Arie Setyaningrum Pamungkas dan Gita Octaviani yang memaparkan kajian representasi Aksi Bela Islam melalui pendekatan observasi atas representasi mobilisasi aksi massa di media sosial secara online daring (dalam jaringan) dan keberlangsungannya di dalam komunitas secara luring (luar jaringan) offline. Dalam kajiannya, para penulis menjabarkan bahwa ruang publik Muslim di Indonesia memberikan peluang yang besar bagi berlangsungnya praktik mediatisasi dakwah, yaitu suatu strategi dakwah untuk kepentingan politik dengan memanfaatkan media. Melalui media sosial seperti Facebook, Instagram, dan bahkan pesan pribadi yang difasilitasi oleh aplikasi WhatsApp dalam smartphone telah mampu melipatgandakan dukungan bagi mobilisasi dukungan aksi yang bermula dari suatu kepentingan politik yang mengusung isu penistaan agama yang dituduhkan kepada Gubernur DKI Jakarta, Ahok dan pada saat itu sedang 
berlangsung kontestasi demokrasi melalui momentum Pilkada di Jakarta. Media sosial memberi pengaruh dalam mempolarisasikan dukungan politik yang cenderung didominasi oleh mobilisasi politik identitas yang mengabaikan kemajemukan dan keragaman Indonesia. Polarisasi ini bahkan dimobilisasikan untuk memperoleh dukungan sentimen politik yang bahkan menjangkau masyarakat luas hingga di luar wilayah Jakarta. Oleh karena itu, mobilisasi massa semacam ini rentan menciptakan nasionalisme sempit yang didasari oleh kesukuan, etnisitas dan agama (tribal nationalism). Artikel keenam disajikan oleh Subkhi Ridho melalui pendekatan analisis wacana mengenai peranan kelas menengah Muslim baru dalam pewacanaan mengenai pluralisme khususnya yang dimunculkan melalui media sosial. Dalam pembahasannya penulis mengajukan suatu kritik terhadap kelas menengah Muslim baru yang bersikap ambivalen dalam menyikapi realitas persoalan pluralisme tetapi tidak memiliki daya kritis terhadap komodifikasi nilai-nilai agama Islam untuk kepentingan ekonomi dan politik. Penulis juga menjabarkan bahwa gagasan pluralisme sebenarnya juga menjadi pembahasan utama di dalam tafsir suci agama Islam dan karenanya upaya untuk mensosialisasikan gagasan kritis ini pada kelas menengah Muslim bertujuan untuk mempraktikkan nilai-nilai Islam yang mengakomodasi praktik-praktik kemanusiaan. Artikel ketujuh disajikan oleh Yessi Nurita Labas dan Daisy Indira Yasmine tentang proses komodifikasi yang terjadi di era masyarakat jejaring melalui fokus studi kasus kreator YouTube Indonesia. Keberadaan industri kreatif melalui industri hiburan online seperti YouTube bukan hanya memberi peluang ekspresi diri, namun juga telah menjadi perpanjangan tangan media pemasaran korporasi dimana komodifikasi telah memanfaatkan kreatifitas, ruang ekspresi diri, dan interaksi antara penonton dan kreator. Keterbukaan di era masyarakat jejaring membuka ruang yang luas untuk memonopoli sumberdaya kreatif di dunia hiburan online. Kondisi semacam ini sekaligus menciptakan peluang eksploitasi pada setiap aktor yang terlibat di dalam proses tersebut. Artikel kedelapan disajikan oleh Reza Putradarma yang menelisik kemunculan industri musik hiphop alternatif di dalam komunitas subkultur di Yogyakarta. Melalui observasi etnografis, penulis mendeskripsikan bagaimana gagasan kreatif dikelola melalui muatan glokalisasi dan hibriditas antara budaya lokal dan global dimana nilai-nilai kearifan Jawa bertemu dengan Barat dalam genre musik hiphop. Kemunculan subkultur grup musik hiphop ini menjelaskan bagaimana industri musik dominan mendapatkan tantangan baru dari kelompok-kelompok musisi yang secara kreatif berusaha membangun komunitas, mengelola kreativitasnya dan bahkan membangun pasarnya sendiri melalui strategi hegemoni tanding (counter-hegemony) yang dikelola baik melalui pemanfaatan medium teknologi media baru (new media) maupun menciptakan komunitasnya sendiri. Kajian mengenai eksistensi subkultur grup musik hiphop ini sekaligus juga menjelaskan adanya kecenderungan baru di dalam kondisi pasar industri hiburan di Indonesia dimana banyak musisi-musisi berusaha melakukan pelawanan 
Jurnal Pemikiran Sosiologi Volume 4 No. 2 , Agustus 2017

terhadap hegemoni industri musik kapitalis dominan yang selama ini mendiktekan kebutuhan konsumer atas selera hiburan. Artikel kesembilan disajikan oleh Vibriza Juliswara yang berusaha mengajukan suatu model pengembangan literasi media khususnya dalam menangkal persebaran ujaran kebencian dan informasi berita palsu (hoax) melalui media sosial. Penulis menjabarkan pentingnya mensosialisasikan kembali nilai-nilai penghargaan terhadap kemajemukan dan keragaman (kebhinnekaan) di Indonesia, bukan hanya secara dogmatis belaka, melainkan melalui edukasi dan ketrampilan di dalam melakukan 'penyaringan' (filter) informasi yang setiap harinya membajiri para pengguna internet dan media sosial (netizen) di Indonesia. Persebaran hoax dan ujaran kebencian dapat ditangkal melalui pengembangan kapasitas model literasi media yang memberi kemampuan untuk mengidentifikasi, mengklasifikasikan, membandingkan, dan memverifikasi beragam informasi yang diterima publik sehingga masyarakat tidak secara gegabah terpancing oleh provokasi negatif yang mengarah pada perpecahan, adu-domba, dan kebencian antar kelompok di dalam masyarakat. Melalui teknik model literasi yang memberdayakan para netizen, maka mereka bukan hanya memiliki pengetahuan tentang bagaimana menyikapi hoax dan ujaran kebencian, tetapi juga ketrampilan di dalam menyerap, mengelola, dan membagikan informasi kepada publik.

Demikianlah sajian-sajian artikel tersebut kami hadirkan sebagai bagian dari upaya dan eksplorasi kritis untuk merangkai 'kebhinnekaan' Indonesia. Pemilihan artikel-artikel tersebut dalam pertimbangan Dewan Redaksi Jurnal Pemikiran Sosiologi UGM didasari oleh kepentingan untuk menghadirkan pentingnya mewacanakan kembali secara kritis kemajemukan dan keragaman bangsa Indonesia yang merupakan kekayaan budaya yang kita dimiliki, tetapi sekaligus memiliki potensi kerentanan. Sosiologi sebagai suatu disiplin ilmu sosial humaniora membuka cakrawala mengenai gagasan-gagasan mengenai bagaimana kebudayaan dibangun oleh suatu bangsa, tetapi sekaligus juga menjabarkan konsekuensi apa saja yang harus dihadapi dalam pembangunan kebudayaan suatu negara-bangsa. Semoga sajian penerbitan ini bermanfaat dan menginspirasi.

Salam,

Dewan Redaksi Jurnal Pemikiran Sosiologi. 